\title{
Analysis of copper-rich precipitates in silicon: chemical state, gettering, and impact on multicrystalline silicon solar cell material
}

\author{
Tonio Buonassisi ${ }^{1,21}$, Matthew A. Marcus ${ }^{3}$, Andrei A. Istratov ${ }^{1,2}$, Matthias Heuer ${ }^{2,4}$, \\ Theodore F. Ciszek ${ }^{5}$, Barry Lai ${ }^{6}$, Zhonghou Cai ${ }^{6}$, and Eicke R. Weber ${ }^{1,2}$ \\ ${ }^{1}$ University of California, Department of Materials Science and Engineering, \\ Berkeley, California 94720 \\ ${ }^{2}$ Lawrence Berkeley National Laboratory, Berkeley, California 94720 \\ ${ }^{3}$ Advanced Light Source, Lawrence Berkeley National Laboratory, Berkeley, California 94720 \\ ${ }^{4}$ University of Leipzig, Scharnhorststr. 20, D-04275 Leipzig, Germany \\ ${ }^{5}$ Siliconsultant, P.O. Box 1453, Evergreen, Colorado 80437 \\ ${ }^{6}$ Advanced Photon Source, Argonne National Laboratory, Argonne, Illinois 60439
}

\section{RECEIPT DATE: June 4, 2004}

\footnotetext{
${ }^{1}$ Corresponding author: buonassisi@alumni.nd.edu
} 


\begin{abstract}
In this study, synchrotron-based $\mathrm{x}$-ray absorption microspectroscopy ( $\mu$-XAS) is applied to identifying the chemical states of copper-rich clusters within a variety of silicon materials, including as-grown cast multicrystalline silicon solar cell material with high oxygen concentration and other silicon materials with varying degrees of oxygen concentration and copper contamination pathways. In all samples, copper silicide $\left(\mathrm{Cu}_{3} \mathrm{Si}\right)$ is the only phase of copper identified. It is noted from thermodynamic considerations that unlike certain metal species, copper tends to form a silicide and not an oxidized compound because of the strong silicon-oxygen bonding energy; consequently the likelihood of encountering an oxidized copper particle in silicon is small, in agreement with experimental data. In light of these results, the effectiveness of aluminum gettering for the removal of copper from bulk silicon is quantified via x-ray fluorescence microscopy ( $\mu-\mathrm{XRF})$, and a segregation coefficient is determined from experimental data to be at least $(1-2) \times 10^{3}$. Additionally, $\mu$-XAS data directly demonstrates that the segregation mechanism of $\mathrm{Cu}$ in $\mathrm{Al}$ is the higher solubility of $\mathrm{Cu}$ in the liquid phase. In light of these results, possible limitations for the complete removal of $\mathrm{Cu}$ from bulk mcSi are discussed.
\end{abstract}

PACS: 78.70; 61.72; 84.60 


\section{INTRODUCTION}

Copper is a ubiquitous contaminant in silicon-based device technology that can be easily introduced into the bulk of silicon wafers. According to the existing data on solubility and diffusivity of $\mathrm{Cu}$ in $\mathrm{Si}^{1-3}$, at only $425^{\circ} \mathrm{C}$ the equilibrium solubility of $\mathrm{Cu}$ in $\mathrm{Si}$ is as high as $10^{13} \mathrm{~cm}^{-3}$, and the diffusivity is such that $\mathrm{Cu}$ can traverse $220 \mu \mathrm{m}$ of single crystalline $\mathrm{p}$-type silicon in under 10 seconds $(\lambda=\sqrt{4 D t})$. According to the current understanding of the electrical properties and defect interactions of copper in silicon $^{4,5}$, interstitial copper is a shallow donor with relatively benign electrical activity. On the other hand, copper-rich precipitates are known to severely reduce the minority carrier diffusion length by forming bands of states within the silicon bandgap, thereby providing very effective pathways for recombination. ${ }^{6-10}$

The precipitation of copper is unfavorable in structurally perfect p-type silicon because of the significant lattice strains involved in the formation of copper-rich precipitates $^{11}$, possibly limited by the relatively lower diffusivity of ejected silicon selfinterstitials, compounded with the energy required to change the charge state of $\mathrm{Cu}$ upon precipitation. ${ }^{5}$ Copper precipitation in bulk p-type silicon can occur if the $\mathrm{Cu}$ contamination level is high and the chemical driving force for precipitation is sufficient to overcome the barrier for precipitation. ${ }^{8,9,12-14}$ More importantly, even in low concentrations copper readily precipitates in the presence of heterogeneous nucleation sites, such as stacking faults or certain types of dislocations. ${ }^{15-18}$ It is also known that metal-rich clusters can be incorporated into structural defects during crystal growth. ${ }^{19}$ 
Multicrystalline silicon (mc-Si), the cost-effective material out of which an increasing $50 \%$ of solar cell modules are currently produced ${ }^{20}$, typically contains high transition metal concentrations combined with a high density and variety of structural defects. Not surprisingly, copper-rich particles have been observed at structural defects in poorly-performing regions of mc-Si solar cell material ${ }^{21-25}$, complementing neutron activation analysis (NAA) data reporting $\mathrm{Cu}$ concentrations in mc-Si as high as $10^{13} \mathrm{~cm}^{-3} \cdot{ }^{26}$ While Cu-rich clusters are undoubtedly not the only type of defect responsible for reducing the efficiencies of mc-Si solar cells, their known recombination activity and repeated observation in poorly-performing regions indicate they most certainly can be a contributing factor.

The chemical states of these $\mathrm{Cu}$-rich clusters has wide-reaching implications for predicting the stability of these clusters, and ultimately, their impact upon mc-Si solar cell devices. ${ }^{22,27}$ For example, it is much more difficult to dissolve and getter copper from copper oxide or copper silicate clusters than from copper silicide, due to the higher binding energy of the metal atoms to those compounds. ${ }^{27}$ Previous studies that have attempted to determine the chemical state of $\mathrm{Cu}$-rich clusters in $\mathrm{Si}$ are largely restricted to TEM-based energy dispersive x-ray spectroscopy (EDX) and diffraction analyses of copper precipitates in samples prepared by in-diffusion of unusually high $\mathrm{Cu}$ concentrations, or grown from a heavily Cu-contaminated melt. ${ }^{28-33}$ In these studies, a species of copper silicide, $\eta-\mathrm{Cu}_{3} \mathrm{Si}$, is the predominantly observed phase.

The question arises as to whether copper-rich clusters in intentionally contaminated samples are of a phase identical to that found in samples containing lower $\mathrm{Cu}$ concentrations, representative of what one might encounter in mc-Si without 
intentional contamination. Studies of these lower $\mathrm{Cu}$ concentrations are now possible with synchrotron-based x-ray microprobe techniques, due to the higher sensitivities and large scanning volumes of these tecniques. ${ }^{21,22} \mathrm{~A}$ recent synchrotron-based x-ray absorption spectroscopy ( $\mu$-XAS) study found that gettering-resistant $\mathrm{Cu}$-rich clusters in oxygen-rich silicon had a shift in the $\mathrm{Cu}$ absorption edge to higher energies, interpreted as a possible indication that oxidized $\mathrm{Cu}$-rich clusters may have formed. ${ }^{27}$

The objective of this study is to clarify these discrepancies in the literature, and to determine the chemical states of copper-rich particles located in a variety of silicon-based materials with varying degrees of oxygen concentration and $\mathrm{Cu}$ contamination pathways: float zone silicon with copper introduced into the melt during crystal growth, copperdiffused $\mathrm{Si}_{0.98} \mathrm{Ge}_{0.02} / \mathrm{Si}$ misfit dislocations, copper-diffused CZ-Si with oxygen precipitates, and as-grown mc-Si without any intentional $\mathrm{Cu}$ contamination. A discussion of the most probable oxidation states of copper-rich and other metal-rich clusters in silicon ensues.

Following the experimental identification and discussion of the chemical state of $\mathrm{Cu}$-rich clusters in $\mathrm{Si}$, it is of interest to quantify the effectiveness of the removal of $\mathrm{Cu}$ from bulk Si by aluminum gettering. Since $\mathrm{Al}$ is used as the ohmic back surface contact material for most silicon-based solar cells, aluminum gettering is a standard part of silicon solar cell processing. It has been reported that copper is readily gettered from silicon to aluminum during even a medium-temperature anneal, ${ }^{34-37}$ yet that some $\mathrm{Cu}$ may resist gettering. ${ }^{27}$ Herein, we report the chemical state and distribution of $\mathrm{Cu}$ within an $\mathrm{Al}$ gettering layer of variable thickness, estimate a segregation coefficient based on experimental x-ray fluorescence microscopy $(\mu-\mathrm{XRF})$ data, and discuss the possible 
physical mechanisms that oppose the complete gettering of $\mathrm{Cu}$ in $\mathrm{mc}-\mathrm{Si}$ to the $\mathrm{Al}$ gettering layer.

\section{METHODOLOGY}

Copper-rich clusters in four types of silicon materials, with varying amounts of oxygen and intentional copper contamination, were investigated in this study. Sample specifications are as follows:

Sample 1: Float zone silicon intentionally contaminated with $3-4 \times 10^{16} \mathrm{Cu} / \mathrm{cm}^{-3}$ during crystal growth. Float zone crystals were grown at the National Renewable Energy Laboratory (see Ref. ${ }^{38}$ for details). The particular crystal growth conditions lead to a high density of structural defects. With no intentional n- or p-type doping, the actual conductivity of the sample was n-type, as evidenced by the rectifying behavior of a thin Pd diode evaporated on the polished and chemically cleaned surface.

Sample 2: Misfit dislocation heterostructure, consisting of a $2 \mu \mathrm{m}$ thick n-type $\mathrm{Si}_{0.98} \mathrm{Ge}_{0.02}$ middle layer between a $2.5 \mu \mathrm{m}$ n-type silicon bottom buffer layer on a $(001)$ silicon substrate and a $2.5 \mu \mathrm{m}$ thick n-type silicon cap layer. At the two interfaces between the $\mathrm{SiGe}$ and $\mathrm{Si}$ layers, a network of $60^{\circ}$ misfit dislocations forms parallel to the surface and propagates in the $\langle 110\rangle$ directions, intersecting at $90^{\circ}$ angles. Copper was intentionally diffused at $800^{\circ} \mathrm{C}$. Samples were fabricated at North Carolina State University (U.S.A.) and copper-contaminated at King's College (U.K.); further details of sample preparation can be found in Ref. 39.

Sample 3: Czochralski silicon containing approximately $1.8 \times 10^{6} \mathrm{~cm}^{-3}$ oxygen precipitates and approximately $1.5 \times 10^{15} \mathrm{~cm}^{-3}$ boron was chosen because of the high 
density of precipitation sites for metals and high precipitated oxygen concentration. The sample was intentionally contaminated with $\mathrm{Cu}$ and annealed at $1200^{\circ} \mathrm{C}$ in forming gas $\left(\mathrm{N}_{2}+5 \% \mathrm{H}_{2}\right)$ ambient for 30 minutes. The anneal was terminated by an air cool.

Sample 4: As-grown, cast mc-Si wafer extracted from near the bottom of the cast mc-Si ingot, where the interstitial oxygen concentration can be as high as $10^{18} \mathrm{~cm}^{-3}$.

To determine the precise location of copper nano- and micro-clusters inside each sample, synchrotron-based x-ray fluorescence microscopy ( $\mu$-XRF) was performed at Beamlines 10.3.1 and 10.3.2 of the Advanced Light Source (ALS) at Lawrence Berkeley National Laboratory, and at Beamline 2-ID-D of the Advanced Photon Source (APS) of Argonne National Laboratory. At the time of measurement, the focusing optics of ALS Beamlines 10.3.1 and 10.3.2 respectively were adjusted to achieve optimum spot sizes (spatial resolutions) of $2 \times 3 \mu \mathrm{m}^{2}$ and $5 \times 7 \mu \mathrm{m}^{2}$, at fluxes of $\sim 1 \times 10^{9}$ photons/s. The zone plate optics of APS Beamline 2-ID-D achieved a spot size of $200 \mathrm{~nm}$ in diameter, with a flux $\sim 10^{10}$ photons/s. The ability to detect metal micro- and nano-clusters in silicon using the $\mu$-XRF technique has been well-established. ${ }^{22,23,40}$ Further details of ALS Beamlines 10.3.1 and 10.3.2 can be found in Ref. 41 and 42, 43 respectively. Details of the APS Beamline 2-ID-D zone plate focusing optics ${ }^{44}$ and beamline ${ }^{45}$ are also available.

In addition to the presence of metal clusters, it is also possible to determine their recombination activity, in-situ at the synchrotron beamline, using the x-ray beam induced current (XBIC) technique. ${ }^{46}$ This technique collects photo-excited minority carriers with a Schottky diode or pn junction in a manner similar to laser- or electron-beam induced current (LBIC/EBIC). By simultaneously recording x-ray induced current via a Keithley 428 current amplifier and x-ray fluorescence data via a Princeton Gamma-Tech Prism 
$\mathrm{Si}(\mathrm{Li})$ detector or 7-element Canberra Ge detector for Beamlines 10.3.1 and 10.3.2

respectively, one can concurrently acquire data on the elemental nature and

recombination activity of metal clusters in silicon with micron-scale spatial resolution. ${ }^{47}$

To determine the chemical state of $\mathrm{Cu}$ in the samples and in the standard materials, synchrotron-based x-ray absorption microspectroscopy ( $\mu$-XAS) was used. $\mu$ XAS is an umbrella group usually divided into two techniques encompassing specific energy ranges: $x$-ray absorption near edge microspectroscopy ( $\mu$-XANES) spans from the absorption edge onset up to $20-50 \mathrm{eV}$ above the absorption edge onset, and extended $x$-ray absorption fine structure microspectroscopy ( $\mu$-EXAFS) spans up to several hundred $\mathrm{eV}$ above the absorption edge. ALS Beamline 10.3.2, which can perform both $\mu$ XANES and $\mu$-EXAFS studies, is equipped with a 2-crystal, fixed-exit $\operatorname{Si}(111)$

monochromator with energy resolution of $\sim 1 \mathrm{eV}$. APS Beamline 2-ID-D, which could perform only $\mu$-XANES at the time of this publication, is equipped with a Kohzu Si(111) monochromator with comparable energy resolution.

Because each compound has a unique $\mu$-XAS spectrum - much the same way it has a unique x-ray diffraction (XRD) pattern - a good correlation between $\mu$-XAS spectra from samples and standard material can yield a positive identification of chemical state. Standards consisting of $\mathrm{Cu}$ foil, $\mathrm{Cu}_{2} \mathrm{O}$ (99+\% purity), $\mathrm{CuO}(97 \%)$, and $\mathrm{Cu}_{5} \mathrm{Si}(99.5 \%)$ were acquired from vendors. Standard material of $\mathrm{Cu}_{3} \mathrm{Si}$ was prepared at the Institute for Mineralogy at the University of Leipzig. The $\mathrm{Cu}_{3} \mathrm{Si}$ reference sample was synthesized by a solid state reaction from high purity ( $>99.999 \%$ ) silicon and copper in an evacuated silica ampoule at $\mathrm{T}=750^{\circ} \mathrm{C}$. For this purpose, $\mathrm{Cu}$ and $\mathrm{Si}$ powders were mixed in nearstoichiometric proportions with a slight abundance of $\mathrm{Si}$, dryly homogenized in an agate 
mortar, and then pressed to a pellet. The sample was annealed as described above for two days and finally quenched in water. The resulting phase was checked by an XRDmeasurement on a Seifert-XRD3000-diffractometer (30mA/40kV; Bragg-Brentanogeometry) equipped with graphite (002) secondary monochromator and a scintillation detector. The powder diffraction pattern was recorded from $5^{\circ}$ to $110^{\circ} 2 \theta$, with a step size of $0.01^{\circ} 2 \theta$ and $30 \mathrm{~s} / \mathrm{step}$, which confirmed that the resulting material was $\eta-\mathrm{Cu}_{3} \mathrm{Si}$. The $\eta-\mathrm{Cu}_{3} \mathrm{Si}$ standard material was also measured with XRD in-situ at ALS Beamline 10.3.2, to confirm the presence of the $\eta-\mathrm{Cu}_{3} \mathrm{Si}$ phase.

$\mu$-XRF, $\mu$-XANES, and $\mu$-EXAFS analyses of Samples 1-3 were performed at ALS 10.3.2, in addition to $\mu$-XRF and XBIC analyses of Sample 1 at both ALS 10.3.1 and 10.3.2. Additionally, $\mu$-XRF and $\mu$-XANES analyses of Sample 4 were performed at APS 2-ID-D. Measurements on standard materials were performed in transmission to avoid overabsorption effects. $\mu$-XAS spectra of $\mathrm{Cu}$-rich clusters in the silicon samples were obtained in fluorescence mode, since the total amount of copper contained in these clusters is below the critical threshold. ${ }^{42}$ Standard material was measured at both beamlines ALS 10.3.2 and APS 2-ID-D to ensure that beamline-specific characteristics such as monochromator energy resolution would not obscure the direct comparison of spectra obtained at different beamlines.

\section{DISTRIBUTION AND CHEMICAL STATE OF CU-RICH CLUSTERS}

Prior to $\mu$-XAS analyses, each Si sample was mapped with $\mu$-XRF to reveal the precise distribution of $\mathrm{Cu}$-rich clusters. The noteworthy observations from $\mu$-XRF maps of each sample are as follows: 
(1) For FZ-Si heavily contaminated with $\mathrm{Cu}$ during crystal growth (Sample 1), irregularly distributed $\mathrm{Cu}$ clusters are observed at structural defects (Fig. 1a). This irregular $\mathrm{Cu}$ decoration is expected for slow-cooled samples, wherein supersaturated $\mathrm{Cu}$ can diffuse to preferred precipitation sites. ${ }^{48}$ The observed $\mathrm{Cu}$-rich clusters are strongly recombination-active, as revealed by XBIC (Fig. 1b). Five Cu-rich clusters in this sample were analyzed by $\mu$-XAS.

(2) $\mathrm{Cu}$-rich precipitates are observed along misfit dislocations in the $\mathrm{Si}_{0.98} \mathrm{Ge}_{0.02} / \mathrm{Si}$ heterostructure (Sample 2). From the $\mathrm{Cu}-\mathrm{K} \alpha$ fluorescence map (Fig. 2), one can clearly see the copper contamination along the network of $60^{\circ}$ misfit dislocations parallel to the surface, which intersect at $90^{\circ}$ angles in agreement with literature observations. ${ }^{49-51}$ The recombination-activity of these precipitates has been well-established by electron beam induced current (EBIC) and XBIC measurements, and is reported elsewhere. ${ }^{39,49,52}$ Two $\mathrm{Cu}$-rich clusters were analyzed by $\mu$-XAS in this sample.

(3) In the CZ-Si sample containing $10^{6} \mathrm{~cm}^{-3}$ oxygen precipitates (Sample 3), approximately $\sim 1.1 \times 10^{6} \mathrm{~cm}^{-3}$ copper clusters are observed (assuming a $\mathrm{Cu}-\mathrm{K} \alpha$ attenuation length of $70 \mu \mathrm{m}$ and an angle of $45^{\circ}$ between the sample surface normal and the detector). Although each $\mathrm{Cu}$-rich cluster covers many pixels in the $\mu$-XRF map (each pixel $=7 \times 7 \mu \mathrm{m}^{2}$ ) to form a disk- or point-like shape, as evidenced in Fig. 3, the average signal strength within the precipitate is low, evidence for the distribution of $\mathrm{Cu}$ in the form of many smaller precipitates. $\mathrm{Cu}$ nanoprecipitates have been observed in infrared transmission microscopy ${ }^{53}, \mathrm{TEM}^{33}$, and etching experiments ${ }^{13}$ to form elliptical, platelike, micron-sized colonies of along preferred crystallographic orientations. Interestingly, the elliptical $\mathrm{Cu}$-rich microcolonies observed in $\mu$-XRF also appear to be aligned to 
certain orientations within the crystal, as shown in Fig. 3. Although the spatial density of these colonies $\left(\sim 1.1 \times 10^{6} \mathrm{~cm}^{-3}\right)$ corresponds well to the density of oxygen precipitates $\left(1 \times 10^{6} \mathrm{~cm}^{-3}\right)$, the morphology of these $\mathrm{Cu}$ clusters appears not to be spherical, indicating that the $\mathrm{Cu}$ atoms in this sample preferred not to homogeneously coat the oxygen precipitates, but either used them or their punched out dislocation loops as nucleation sites for $\mathrm{Cu}$ microcolony formation. Three $\mathrm{Cu}$-rich clusters were analyzed by $\mu$-XAS in this sample.

(4) In the as-grown cast mc-Si material (Sample 4), Cu-rich clusters were located at a grain boundary in the material, together with similar amounts of $\mathrm{Ni}$ and less abundant Fe, although no intentional contamination was performed. The $\mu$-XRF map in Fig. 4 shows the $\mathrm{Cu}$ distribution along a representative region of the grain boundary. Although the cluster sizes were smaller than the x-ray beam spot size of $200 \mathrm{~nm}$, the number of $\mathrm{Cu}$ atoms per cluster was determined to fall within the range of $3 \times 10^{7} \pm 1.5 \times 10^{7}$ by comparison with standard materials. Were all these $\mathrm{Cu}$ atoms contained within one large spherical $\mathrm{Cu}_{3} \mathrm{Si}$ particle, following the approximation presented in Ref. 54, the diameters of these particles would range between $100 \pm 15 \mathrm{~nm}$. However, it is also possible these $\mathrm{Cu}_{3} \mathrm{Si}$ molecules are distributed among a colony of nanoparticles as reported in TEM studies of intentionally-contaminated monocrystalline $\mathrm{Si}^{33}{ }^{33}$ Seven $\mathrm{Cu}$-rich clusters were analyzed by $\mu$-XANES in this sample.

$\mathrm{Cu}$ K-edge $\mu$-XANES scans of the copper-rich clusters in all four samples yielded strikingly similar spectra to $\mathrm{Cu}_{3} \mathrm{Si}$ standard material (Fig. 5b, c). A $\mu$-XANES comparison of different standard materials (Fig. 5a) reveals that the Cu K-edge absorption onset energy of $\mathrm{Cu}_{3} \mathrm{Si}$ matches that of the $\mathrm{Cu}_{2} \mathrm{O}$ standard, and is shifted as 
compared to that of metallic $\mathrm{Cu}$ standard. The $\mathrm{Cu}$ K-edge absorption energy shift of $\mathrm{Cu}_{3} \mathrm{Si}$ relative to $\mathrm{Cu}$ metal is not typical for all metal silicides. Iron metal and silicides, for example, have identical Fe K-edge x-ray absorption onset energies, unlike oxidized iron species that have K-edge onsets shifted to higher energies by amounts proportional to the Fe charge state. ${ }^{55,56}$

In our opinion, this behavior of $\mathrm{Cu}$ stems from the unique electronic properties of $\mathrm{Cu}$ in $\mathrm{Si}$. Copper dissolved in p-type silicon is well-known to diffuse predominantly as $\mathrm{Cu}_{\mathrm{i}}{ }^{+1}$ Recent $a b$ initio Hartree-Fock calculations published by S. K. Estreicher ${ }^{5}$ indicate that $\mathrm{Cu}_{\mathrm{i}}^{+}$will not diffuse as a compact $[\mathrm{Ar}] 3 \mathrm{~d}^{10} 4 \mathrm{~s}^{0}$ sphere, but rather, it will promote some its electrons from the $3 \mathrm{~d}$ to the $4 \mathrm{sp}$ orbitals to form weak covalent bonds with nearby silicon atoms. Similarly, copper atoms precipitated at certain internal voids are predicted to promote a small fraction of their electrons to $4 \mathrm{sp}$ orbitals for covalent overlap with neighboring silicon atoms. ${ }^{5}$ Macroscopic studies on and models of the properties of copper silicides have also indicated a hybridization of the valence $\mathrm{Cu}$ and $\mathrm{Si}$ orbitals. $^{29,57-59}$ The increased delocalization of $\mathrm{Cu}$ valence electrons can qualitatively explain the $\mathrm{Cu}-\mathrm{K}$ absorption edge shift to higher energies: as they are photo-excited out of the atom, $\mathrm{Cu} 1 \mathrm{~s}$ core electrons experience a greater Coulombic attraction with the $\mathrm{Cu}$ nucleus due to reduced electron screening, and thus require higher x-ray energies for photoionization.

In agreement with the trend observed in the $\mu$-XANES data, the $\mu$-EXAFS spectra of $\mathrm{Cu}_{3} \mathrm{Si}$ standard material and $\mathrm{Cu}$-rich clusters in Samples 1-3 again match very well, as shown in Fig. 6. It is noticed that the $\mu$-EXAFS data for a more $\mathrm{Cu}$-rich phase of copper silicide, $\mathrm{Cu}_{5} \mathrm{Si}$, are shifted in phase and amplitude relative to the sample data, making a 
poor fit. It is thus concluded that the chemical form of copper in Samples 1-3 is very similar, if not identical, to $\mathrm{Cu}_{3} \mathrm{Si}$, and definitely not an oxidized species nor a copper-rich silicide.

\section{OXIDATION OF COPPER AND OTHER METALS IN SI}

In the past, it has been suggested that oxidized metallic precipitates may form within silicon because many species of metal atom, e.g. $\mathrm{Cu}$ and $\mathrm{Fe}$, have higher binding

energies to oxidized compounds such as silicates and oxides than to silicides. ${ }^{22,27,56}$ While it is true that metals bond strongly to oxygen, the same can also be said for silicon, and thus an analysis of whether a metallic oxide, silicate, or silicide will form should take this competitive oxidation potential into consideration. It is known that oxygen can form a very stable and electrically inactive interstitial complex with silicon $\left(\mathrm{O}_{\mathrm{i}}\right)$, not to mention $\mathrm{SiO}_{2}$. Table I reproduces the enthalpy of formation per oxygen atom (the figure of merit in a balanced equation) from individual elements for a selection of oxidized species, demonstrating that when $[\mathrm{Si}]>>[\mathrm{O}]>[\mathrm{Cu}]$, equilibrium thermodynamics predicts that silicon will be the predominant oxidized species.

While the precise values of enthalpies of formation cited in Table I do not reflect the additional detailed calculations necessary to account for the formation of a species within a silicon lattice, this treatment provides the conceptual framework from which to analyze the prospect of a metal forming an oxidized species. In the presence of silicon, a strong competitor for oxygen, $\mathrm{Cu}$ will likely be reduced or remain unoxidized. This has been demonstrated on a macroscopic level, via the observation that an oxidizing $\mathrm{Cu}_{3} \mathrm{Si}$ layer will first form $\mathrm{Cu}_{2} \mathrm{O}$ on $\mathrm{Cu}_{3} \mathrm{Si}$, then progress to a final state of $\mathrm{SiO}_{2}$ on $\mathrm{Cu}_{3} \mathrm{Si}$ after 
annealing. ${ }^{60}$ Microscopic calculations predict that although $\mathrm{Cu}_{\mathrm{i}}$ is attracted to $\mathrm{O}_{\mathrm{i}}$ because it fits nicely into the void at the interstitial site near the $\mathrm{O}_{\mathrm{i}}$, no covalent $\mathrm{Cu}-\mathrm{O}$ bonding occurs, ${ }^{61}$ again confirming that $\mathrm{Si}$ wins out over $\mathrm{Cu}$ when competing for oxygen. Based on these observations and our $\mu$-XAS measurements, it is concluded that $\mathrm{Cu}$ in the presence of $\mathrm{Si}$ with $[\mathrm{O}] \ll<\mathrm{Si}]$ will not tend to form stable chemical bonds with oxygen, and thus will likely either form non-oxidized precipitates, out-diffuse, or remain dissolved if solubility permits.

This treatment can be generalized to other metal and metal-oxide or -silicate species. For example, the values in Table I would suggest that Hf would form strong bonds to oxygen even if the heat of formation of hafnium silicide were considered, as was experimentally observed by Murarka and Chang ${ }^{62}$. On the other hand, it appears unlikely that iron will form oxidized precipitates within the silicon bulk, if $[\mathrm{Si}]>>[\mathrm{O}]>[\mathrm{Fe}]$, as confirmed by multiple sightings of sub-micron $\mathrm{FeSi}_{2}$ inclusions in mc-Si. ${ }^{63} \mathrm{~A}$ good general review of these thermodynamic principles is presented by d'Heurle et al. ${ }^{64}$

There are likely to exist alternative pathways for the introduction of oxidized metal species into mc-Si material. Large oxidized iron particles could be introduced into the melt, survive the crystal growth process, and become trapped, e.g., between grain boundaries during crystal growth. For example, iron in stainless steel readily oxidizes at temperatures above $1000^{\circ} \mathrm{C},{ }^{55}$ and the melting temperature of $\mathrm{Fe}_{2} \mathrm{O}_{3}$ is $150^{\circ} \mathrm{C}$ higher than that of silicon. While molten silicon would invariably attack these foreign particles and reduce their size, the observation by McHugo et al. ${ }^{56}$ of partially-oxidized Fe inside a $\mathrm{Fe}+\mathrm{Ni}+\mathrm{Cr}$ particle cluster $>15 \mu \mathrm{m}$ in diameter seems to suggest this contamination pathway may indeed occur. The same pathway is not predicted to occur for oxidized $\mathrm{Cu}$ 
particles, as the low melting temperatures of both $\mathrm{Cu}_{2} \mathrm{O}\left(1235^{\circ} \mathrm{C}\right)$ and $\mathrm{CuO}\left(1326^{\circ} \mathrm{C}\right)$ imply that such particles would quickly dissolve in molten silicon $\left(1414^{\circ} \mathrm{C}\right)$. Experimental evidence up to this point has shown no evidence for oxidized $\mathrm{Cu}$-rich clusters inside silicon crystals.

\section{AL-GETTERING AND DISSOLUTION OF CU PRECIPITATES}

Aluminum gettering was performed on a $\mathrm{Cu}$-contaminated sample to study the gettering mechanism and its effectiveness. A $700 \mu \mathrm{m}$-thick CZ sample containing $10^{6} \mathrm{~cm}^{-3}$ oxygen precipitates was copper-contaminated by a diffusion anneal at $1200^{\circ} \mathrm{C}$. After the sample was cooled to room temperature, a $5 \mu \mathrm{m}$ aluminum layer was evaporated onto one surface of the sample through a wire mesh. Subsequently, the sample was annealed at $800^{\circ} \mathrm{C}$ for 2 hours in forming gas ambient in a horizontal furnace to getter the $\mathrm{Cu}$ to the $\mathrm{Al}$. The sample was then removed from the furnace onto an aluminum plate, where it cooled rapidly.

The aluminum gettering layer was subsequently observed with an optical microscope (Fig. 7a) and scanned with $\mu$-XRF (Fig. 7b), revealing copper present only where aluminum was deposited through the wire mesh. No $\mathrm{Cu}$ was detected in an $\mathrm{Al}$ layer of the same thickness evaporated onto a float zone control sample, which confirms cleanliness of the evaporated copper. The effectiveness of aluminum gettering for the removal of $\mathrm{Cu}$ from bulk $\mathrm{Si}$ is a likely indication of a weak binding energy of $\mathrm{Cu}$ to $\mathrm{Cu}_{3} \mathrm{Si}$ clusters, unlike what one would expect from an oxidized species.

The chemical state of $\mathrm{Cu}$ in the $\mathrm{Al}$ gettering layer provides an indication of the gettering mechanism. $\mu$-EXAFS analyses of the chemical state of copper gettered to 
thicker regions of $\mathrm{Al}$ (indicated by a dashed arrow in Fig. 7b) indicate that copper has formed a species very similar to that identified in Ref. ${ }^{67}$, a dilute $\mathrm{Cu}$ solution in $\mathrm{Al}$ (Fig. 8). This result directly confirms the generally accepted opinion ${ }^{68}$ that the mechanism of segregation of metals in aluminum is their higher solubility in the liquid phase.

A different chemical state of $\mathrm{Cu}$ is identified in thinly dispersed aluminum particles on the backside (indicated by a solid arrow in Fig. 7b). The $\mu$-EXAFS from this location (Fig. 9), while not making a perfect match with any of our standards, is most similar to the $\theta-\mathrm{Al}_{2} \mathrm{Cu}$ standard material of Ref ${ }^{67}$. Precipitates of $\theta-\mathrm{Al}_{2} \mathrm{Cu}$, which are known to form within aluminum layers, are very unstable and dissolve rapidly at temperatures above $400^{\circ} \mathrm{C}$. Therefore, there is no indication that the presence of this phase would change the segregation coefficient of copper to aluminum at higher temperatures. At the moment, it cannot be unambiguously determined why this different phase of copper is observed only in thin Al layers. One may speculate that the percentage composition of copper in the thin aluminum layer increased substantially during cooldown, either via relaxation gettering of copper from the bulk and/or a strong temperature dependence of the segregation coefficient. It has been observed, for example, that $\mathrm{Al}$ is effective at gettering $\mathrm{Cu}$ from $\mathrm{Si}$ at temperatures as low as $540^{\circ} \mathrm{C} .^{34}$

The increased solubility of $\mathrm{Cu}$ in the $\mathrm{Al}$ gettering layer, the presumably weak binding energy of $\mathrm{Cu}$ to $\mathrm{Cu}_{3} \mathrm{Si}$, and the high diffusivity of $\mathrm{Cu}$ in $\mathrm{Si}$ suggest that $\mathrm{Al}$ gettering is indeed very effective for removing $\mathrm{Cu}$ from bulk silicon. However, this does not imply that a standard $\mathrm{Al}$ gettering procedure, with a micron of $\mathrm{Al}$ and an $800^{\circ} \mathrm{C}$ anneal, would remove all $\mathrm{Cu}$ from the Si bulk to below the detection limit. The residual concentration of $\mathrm{Cu}$ in the silicon wafer after $\mathrm{Al}$ gettering is determined by three 
parameters, the thicknesses of the silicon substrate, the thickness of the aluminum layer, and the segregation coefficient, i.e. the ratio of the equilibrium solubilities of copper in aluminum $\left(c_{\mathrm{Al}}\right)$ and in silicon $\left(c_{\text {bulk }}\right)$ at a given temperature:

$$
k_{T} \equiv \frac{c_{\mathrm{Al}}}{c_{\text {bulk }}}
$$

The segregation coefficient $k$ can be derived experimentally from the $\mu$-XRF map in Fig. $7 \mathrm{~b}$ by taking into consideration the $\mathrm{Cu}$ counts in the thick $\mathrm{Al}$ layer vs. the counts in the bare silicon bulk, the thicknesses of these two layers, and the XRF attenuation lengths of the $\mathrm{Cu}-\mathrm{K} \alpha$ fluorescence signal in these two layers. The segregation coefficient as defined in Eq. 1 for the sample shown in Fig. $7 \mathrm{~b}$ is estimated to be at least $(1-2) \times 10^{3}$. This value is a lower estimate since a parasitic background $\mathrm{Cu}$ signal measured by the fluorescence detector, although much too weak to disturb $\mu$-XAS measurements, is likely to have produced an artificially high $\mathrm{Cu}$ count rate on the bare silicon bulk. Nevertheless, this value is close to what one would expect assuming a solubility of $\mathrm{Cu}$ in the Al-Si layer of about $0.1-1$ at. $\%$ and a $\mathrm{Cu}$ solubility in $\mathrm{Si}$ at $800^{\circ} \mathrm{C}$ of $5.5 \times 10^{16} \mathrm{~cm}^{-3}$, while being consistent with earlier results ${ }^{35}$ providing $k>1 \times 10^{3}$.

With the estimated segregation coefficient $k=2 \times 10^{3}$ and typical solar cell parameters for wafer thickness $d=240 \mu \mathrm{m}$ and Al layer thickness $w=1 \mu \mathrm{m}$, one can predict from the following equation (from $\operatorname{Ref}^{69}$ ):

$$
\frac{[\mathrm{Cu}] \text { in Bulk After Gettering }}{[\mathrm{Cu}] \text { in Bulk Before Gettering }} \equiv \frac{c_{\text {bulk }}}{c_{\mathrm{o}}}=\frac{c_{\text {bulk }}}{\left(\frac{c_{\text {bulk }} \cdot d+c_{\mathrm{Al}} \cdot w}{d}\right)}=\frac{1}{1+\frac{k \cdot w}{d}}
$$


that an upper limit of about $90 \%$ of the total copper content can be gettered from the bulk by segregation to the $\mathrm{Al}$ layer. With a ten times higher segregation coefficient, $k=10^{4}$, and all other parameters constant, the same calculation predicts an upper limit of over $97 \%$.

It follows from Eq. 2 that the much lower thickness of the Al layer than that of the $\mathrm{Si}$ wafer leads to a much faster increase of $\mathrm{Cu}$ concentration in the Al layer than its decrease in $\mathrm{Si}$. Thus, when equilibrium is reached, $\mathrm{Cu}$ concentration in the bulk may only decrease by a relatively small factor. It is likely that the remaining dissolved $\mathrm{Cu}$ in the bulk will re-precipitate during cooling, especially with the high density of structural defects present in mc-Si. This is consistent with numerous $\mu$-XRF observations of $\mathrm{Cu}-$ rich clusters at structural defects in Al-gettered or fully processed mc-Si. ${ }^{21,23-25}$ Irrespective of the precise value of $k$, it follows from Eq. 2 that thicker Al layers should result in the removal of a larger fraction of the total $\mathrm{Cu}$ from the bulk during gettering.

Other mechanisms may also be responsible for retarding or inhibiting the complete dissolution and removal of all $\mathrm{Cu}_{3} \mathrm{Si}$ clusters during gettering. $\mathrm{Cu}_{3} \mathrm{Si}$ clusters, or individual $\mathrm{Cu}$ atoms, may be stabilized either by the lattice strains of adjacent structural defects or other metal clusters. ${ }^{21,70}$ Specifically, the chemical interactions between $\mathrm{Cu}$ and other metal species (of which mc-Si contains an abundance ${ }^{24,26}$ ) are not well understood at the present time. The singular result of all these effects would likely be a somewhat lower effective segregation coefficient for mc-Si than that for singlecrystalline silicon. As a consequence, more $\mathrm{Cu}$ is likely to remain within bulk mc-Si after Al gettering than sc-Si. Additionally, it has also been suggested that relatively slowlydiffusing Si self-interstitials may play a rate-limiting role in precipitate dissolution, as 
these are needed to counterbalance the volumetric shrinkage associated with the dissolving $\mathrm{Cu}_{3} \mathrm{Si}$ precipitates. ${ }^{27}$ In any case, a two-step aluminum gettering treatment, consisting of a high temperature step to fully dissolve $\mathrm{Cu}$ from $\mathrm{Cu}_{3} \mathrm{Si}$ clusters, followed by a gradual lowering of the temperature to promote the diffusion of $\mathrm{Cu}_{\mathrm{i}}^{+}$to the $\mathrm{Al}$ gettering layer, may be a viable alternative to optimize the removal of $\mathrm{Cu}$ from bulk $\mathrm{Si}$.

\section{SUMMARY AND CONCLUSIONS}

Synchrotron-based x-ray microprobe techniques have been employed to identify the chemical state of copper clusters in a variety of silicon materials with varying degrees of copper contamination and oxygen concentrations. A good match of $\mu$-XAS spectra between $\mathrm{Cu}$-rich clusters in $\mathrm{Si}$ and $\mathrm{Cu}_{3} \mathrm{Si}$ standard material allows one to conclude that $\mathrm{Cu}$-rich clusters in all four studied materials are indeed $\mathrm{Cu}_{3} \mathrm{Si}$. In $\mu$-XANES analyses, the $\mathrm{K}$ absorption edge of $\mathrm{Cu}_{3} \mathrm{Si}$ is shifted to higher energies. This can be explained by the delocalization of some $\mathrm{Cu}-3 \mathrm{~d}$ valence electrons in the presence of silicon neighbors due to the covalent character of the bonding. The absorption onset edge shift is concluded not to be due to the oxidation of $\mathrm{Cu}$ atoms within these clusters.

The likelihood of forming oxidized metal species within silicon is discussed on the basis of this experimental evidence, previous work, and thermodynamic considerations. It is concluded that certain metals such as $\mathrm{Cu}$ and $\mathrm{Fe}$ are unlikely to form oxidized species within a silicon matrix because silicon bonds to oxygen more strongly than do these metals. On the other hand, certain metals such as $\mathrm{Hf}$ bond to $\mathrm{O}$ more strongly than does $\mathrm{Si}$, and thus it is predicted that those metals will form oxidized 
complexes in Si. Furthermore, the possibility is suggested that oxidized iron particles may be present in mc-Si wafers via contamination of the melt by foreign particles.

Aluminum gettering is shown to be very effective at gettering copper from silicon, a natural consequence of the fact that copper is only weakly bound to copper silicide particles, and thus at higher temperatures $\mathrm{Cu}$ can readily diffuse to the $\mathrm{Al}$ layer where its solubility was experimentally determined to increase by at least three orders of magnitude. $\mu$-EXAFS reveals that the chemical state of $\mathrm{Cu}$ in thick $\mathrm{Al}$ gettering layers matches well that of a solid solution of $\mathrm{Cu}$ in $\mathrm{Al}$, consistent with the notion that the mechanism of segregation of copper in aluminum is its higher solubility in the liquid phase, which does not necessarily imply any chemical bonding of copper to aluminum. Despite its effectiveness, $\mathrm{Al}$ gettering does not remove all $\mathrm{Cu}$ from the bulk. The segregation coefficient and the relative thicknesses of the $\mathrm{Al}$ and $\mathrm{Si}$ layers determine the ungettered fraction of $\mathrm{Cu}$, which may promptly re-precipitate at the most stable heterogeneous nucleation sites within the bulk upon cooling. In addition, a few possible mechanisms retarding the dissolution of $\mathrm{Cu}_{3} \mathrm{Si}$ clusters have been described, namely stabilization by the lattice strains of nearby structural defects and/or other metal clusters.

\section{ACKNOWLEDGEMENTS}

Many thanks go to S. K. Estreicher and M. A. Van Hove for the useful discussions concerning the delocalization of $\mathrm{Cu}$ valence electrons in $\mathrm{Si}$, to $\mathrm{J}$. Kalejs and R. Gronsky for suggestions concerning metal inclusion formation during crystal growth, to U. Wulf for discussion of thermodynamics, and to W. Schröter for encouraging discussion. We are much obliged to W. Seifert and M. Kittler for providing the SiGe/Si 
heterostructure. M. Heuer thanks the Deutsche Forschungsgemeinschaft for funding the project HE 3570/1-1. Impurity-doped float-zone silicon crystal growth at the National Renewable Energy Laboratory was supported by U.S. Department of Energy Contract No. DE-AC36-99G010337. This work was funded by NREL Subcontract No. AAT-231605-03. The operations of the Advanced Light Source at Lawrence Berkeley National Laboratory are supported by the Director, Office of Science, Office of Basic Energy Sciences, Materials Sciences Division, of the U.S. Department of Energy under Contract No. DE-AC03-76SF00098. Use of the Advanced Photon Source was supported by the U.S. Department of Energy, Office of Science, Office of Basic Energy Sciences, under Contract No. W-31-109-ENG-38. 


\section{Figure captions}

FIG 1. (a) X-ray beam induced current and (b) $\mathrm{Cu}-\mathrm{Ka}$ X-ray fluorescence microscopy maps of float zone silicon contaminated with $(3-4) \times 10^{16} \mathrm{Cu} \mathrm{cm}^{-3}$ during crystal growth. Notice the strong correlation between the presence of copper-rich clusters (b) and the decrease of current collection efficiency (a).FIG 2. Cu-Ka X-ray fluorescence microscopy map of a $\mathrm{Cu}$-contaminated $\mathrm{Si}_{0.98} \mathrm{Ge}_{0.02} / \mathrm{Si}$ heterostructure. The misfit dislocations parallel to the surface, intersecting at $90^{\circ}$, are heavily decorated with clusters of $\mathrm{Cu}$, confirming the tendency of $\mathrm{Cu}$ to precipitate in the vicinity of structural defects.

FIG 3. $\mathrm{Cu}$-Ka X-ray fluorescence microscopy map of $\mathrm{Cu}$-contaminated Czochralski silicon with $\sim 10^{6}$ oxygen precipitates per $\mathrm{cm}^{3}$. Elliptical Cu-rich clusters can be observed, oriented along preferred crystallographic orientations.

FIG 4. $\mathrm{Cu}-\mathrm{K} \alpha \mathrm{x}$-ray fluorescence microscopy map along a grain boundary of asgrown cast multicrystalline silicon. Despite no intentional contamination, $\mathrm{Cu}$-rich clusters are present.

FIG 5. $\mu$-XANES showing the spectra of standard materials (a), and then the excellent match of $\mathrm{Cu}$-rich clusters in a variety of silicon materials with the $\mathrm{Cu}_{3} \mathrm{Si}$ standard (b,c, taken at different beamlines). Sample descriptions are provided in Sections II and III. Notice in (a) that the edge onset energy of $\mathrm{Cu}_{3} \mathrm{Si}$ is not coincident with metallic $\mathrm{Cu}$ as would be expected from a metal-silicide, but is shifted by $+1 \mathrm{eV}$. This can be understood as an effect of the delocalization of $\mathrm{Cu}-3 \mathrm{~d}$ electrons in the presence of $\mathrm{Si}$.

FIG 6. $\mu$-EXAFS spectra comparing $\mathrm{Cu}$-rich particles in $\mathrm{Si}$ with $\mathrm{Cu}_{3} \mathrm{Si}$ and $\mathrm{Cu}_{5} \mathrm{Si}$ standard materials. It is clear that the chemical form of the $\mathrm{Cu}$-rich clusters within the samples is most similar to the $\mathrm{Cu}_{3} \mathrm{Si}$ standard material, not the $\mathrm{Cu}$-rich silicide. Despite 
variations of copper contamination pathway and oxygen concentration between the three samples, the $\mu$-EXAFS spectra show little deviation from $\mathrm{Cu}_{3} \mathrm{Si}$.

FIG 7. (a) Optical microscope image of the surface of a Cu-contaminated CZ-Si sample with $10^{6} \mathrm{~cm}^{-3}$ oxygen precipitates. This sample was annealed at $800^{\circ} \mathrm{C}$ for 2 hours after squares of aluminum were evaporated onto the surface through a wire mesh. (b) $\mathrm{Cu}$ $\mathrm{K} \alpha \mathrm{x}$-ray fluorescence microscopy image for the region highlighted in (a) shows the high concentration of $\mathrm{Cu}$ gettered to the thick $\mathrm{Al}$ squares (note log XRF scale), and the fine dusting of $\mathrm{Cu}$ in tiny $\mathrm{Al}$ particles between the squares. The dashed and solid arrows denote locations of $\mu$-EXAFS scans in Figures 7 and 8, respectively.

FIG 8. EXAFS of $\mathrm{Cu}$ gettered to thick regions of $\mathrm{Al}$ (dashed arrow in Fig. 6b). Notice the fairly good agreement with the standard material of dilute $\mathrm{Cu}$ dissolved in $\mathrm{Al}$. (Standards from Ref. 67.)FIG 9. EXAFS of Cu gettered to thin regions of $\mathrm{Al}$ (solid arrow in Fig. 6b). Notice the difference between this spectrum and that of the thicker regions of $\mathrm{Al}$ (Fig. 7). The progression of the measured spectrum from dilute $\mathrm{Cu}$ in $\mathrm{Al}$ to $\mathrm{q}-\mathrm{Al}_{2} \mathrm{Cu}$ indicates an increasing saturation of $\mathrm{Al}$ with gettered $\mathrm{Cu}$. (Standards from Ref. 67.) 


\section{REFERENCES}

$1 \quad$ R. N. Hall and J. H. Racette, J. Appl. Phys. 35, 379 (1964).

2 E. R. Weber, Appl. Phys. A: Solids Surf. 30, 1 (1983).

3 A. A. Istratov, C. Flink, H. Hieslmair, E. R. Weber, and T. Heiser, Phys. Rev. Lett. 81, 1243 (1998).

A. A. Istratov and E. R. Weber, J. Electrochem. Soc. 149, G21 (2002).

S. K. Estreicher, Phys. Rev. B 60, 5375 (1999).

J.-L. Maurice and C. Colliex, Appl. Phys. Letters 55, 241 (1989).

A. Broniatowski, Phil. Mag. B 66, 767 (1992).

A. A. Istratov, H. Hedemann, M. Seibt, O. F. Vyvenko, W. Schröter, T. Heiser, C.

Flink, H. Hieslmair, and E. R. Weber, J. Electrochem. Soc. 145, 3889 (1998).

M. Seibt, H. Hedemann, A. A. Istratov, F. Riedel, A. Sattler, and W. Schröter, Phys. stat. sol. (a) 171, 301 (1999).

R. Sachdeva, A. A. Istratov, and E. R. Weber, Appl. Phys. Lett. 79, 2937 (2001).

M. Seibt, in Crystalline defects and contamination: their impact and control in

device manufacturing II, edited by B. O. Kolbesen, C. Claeys, P. Stallhofer and F. Tardif (The Electrochem. Soc., Pennington, 1997), p. 243.

12 M. Seibt, in Semiconductor Silicon 1990, edited by H. R. Huff, K. G. Barraclough and J. I. Chikawa (The Electrochem. Soc., Pennington, 1990), p. 663. M. Seibt and K. Graff, J. Appl. Phys. 63, 4444 (1988). Istratov, and E. R. Weber, Phys. Rev. Lett. 85, 4900 (2000). W. C. Dash, J. Appl. Phys. 27, 1193 (1956). 
B. Shen, T. Sekiguchi, J. Jablonski, and K.Sumino, J. Appl. Phys. 76, 4540 (1994).

W. C. Dash, J. Appl. Phys. 30, 459 (1959).

A. J. R. de Kock, Appl. Phys. Letters 16, 100 (1970).

J. P. Kalejs, B. Bathey, and C. Dubé, J. Crystal Growth 109, 174 (1991).

IEA-PVPS: International Energy Agency - Photovoltaic Power Systems Program, 2003.

S. A. McHugo, Appl. Phys. Letters 71, 1984 (1997).

S. A. McHugo, A. C. Thompson, A. Mohammed, G. Lamble, I. Périchaud, S. Martinuzzi, M. Werner, M. Rinio, W. Koch, H.-U. Höfs, and C. Häßler, J. Appl. Physics 89, 4282 (2001).
A. A. Istratov, H. Hieslmair, O. F. Vyvenko, E. R. Weber, and R. Schindler, Solar Energy Materials \& Solar Cells 72, 441 (2002).

A. A. Istratov, T. Buonassisi, R. J. McDonald, A. R. Smith, R. Schindler, J. A.

Rand, J. P. Kalejs, E. R. Weber, J. Appl. Phys. 94, 6552 (2003).

T. Buonassisi, O. F. Vyvenko, A. A. Istratov, E. R. Weber, G. Hahn, D. Sontag, J.

P. Rakotoniaina, O. Breitenstein, J. Isenberg, and R. Schindler, J. Appl. Physics 95, 1556 (2004).

D. Macdonald, A. Cuevas, A. Kinomura, Y. Nakano, in 29th Photovoltaic Specialists Conference Proceedings (IEEENew Orleans, USA, 2002), p.285. S. A. McHugo, A. Mohammed, A. C. Thompson, B. Lai, and Z. Cai, J. Appl. Phys. 91, 6396 (2002).

E. Nes and J. Washburn, J. Appl. Phys. 43, 2005 (1972). 
G. Das, J. Appl. Phys. 44, 4459 (1973).

30 E. Nes and G. Lunde, J. Appl. Phys. 43, 1835 (1972).

J. K. Solberg, Acta Cryst. A34, 684 (1978).

R. Rizk, X. Portier, G. Allais, and G. Nouet, J. Appl. Phys. 76, 952 (1994).

M. Seibt, M. Griess, A. A. Istratov, H. Hedemann, A. Sattler, and W. Schröter, Phys. stat. sol. (a) 166, 171 (1998).

R. D. Thompson and K. N. Tu, Appl. Phys. Letters 41, 440 (1982).

L. A. Verhoef, P. P. Michiels, S. Roorda, W.C. Sinke, and R.J.C. Van Zolingen, Mat. Sci. Engineering B7, 49 (1990).

H. Hieslmair, S. A. McHugo, and E. R. Weber, in 25th IEEE Photovoltaic Specialists Conference (IEEE, Washington D.C., 1996), p. 441.

G. A. Petersen and S. M. Myers, J. Appl. Phys. 89, 4269 (2001).

T. F. Ciszek and T. H. Wang, J. Crystal Growth 237-239, 1685 (2002).

M. Kittler, C. Ulhaq-Bouillet, and V. Higgs, J. Appl. Phys. 78, 4573 (1995).

T. Buonassisi, M. Heuer, O. F. Vyvenko, A. A. Istratov, E. R. Weber, Z. Cai, B. Lai, T. F. Ciszek, and R. Schindler, Physica B 340-342, 1137 (2003).

J. H. Underwood, A. C. Thompson, Y. Wu, R. D. Giauque, K. W. Jones, and M. L. Rivers, Nucl. Instrum. Methods in Physics Research A 266, 318 (1988).

A. Manceau, M. A. Marcus, and N. Tamura, in Applications of synchrotron radiation in low-temperature geochemistry and environmental science, edited by P. Fenter and N. C. Sturchio (Mineralogical society of America, Washington, DC, 2002), Vol. 49, p. 341. 
M.A. Marcus, A. A. MacDowell, R. Celestre, A. Manceau, T. Miller,

H.A. Padmore, R.E. Sublett, J. Synchrotron Radiation 11, 239 (2004).

44 W. Yun, B. Lai, Z. Cai, J. Maser, D. Legnini, E. Gluskin, Z. Chen, A. A.

Krasnoperova, Y. Vladimirsky, F. Cerrina, E. Di Fabrizio, and M. Gentili, Rev.

Sci. Instrum. 70, 2238 (1999).

45 Z. Cai, B. Lai, W. Yun, P. Ilinski, D. Legnini, J. Maser, and W. Rodrigues, AIP

Conf. Proc. 521, 31 (2000).

46 O. F. Vyvenko, T. Buonassisi, A. A. Istratov, H. Hieslmair, A. C. Thompson, R.

Schindler, and E. R. Weber, J. Appl. Phys. 91, 3614 (2002).

47 O. F. Vyvenko, T. Buonassisi, A. A. Istratov, and E.R.Weber, J. Physics:

Condensed Matter 16, S141 (2003).

48

B. Shen, T. Sekiguchi, R. Zhang, Y. Shi, H. Shi, K. Yang, Y. Zheng, and K.

Sumino, Jap. J. Appl. Physics 35, 3301 (1996).

49 T. S. Fell and P. R. Wilshaw, Journal de Physique IV 1, C6 (1991).

50 D. M. Lee and G. A. Rozgonyi, Appl. Phys. Lett. 65, 350 (1994).

51 G. Kissinger, G. Morgenstern, and H. Richter, J. Appl. Phys. 75, 4994 (1994).

52 O. F. Vyvenko, T. Buonassisi, A. A. Istratov, E. R. Weber, M. Kittler, and W.

Seifert, J. Physics: Condensed Matter 14, 13079 (2002).

53 G. H. Schwuttke, J. Electrochem. Soc. 108, 163 (1961).

54 S. A. McHugo, A. C. Thompson, C. Flink, E. R. Weber, G. Lamble, B. Gunion, A. MacDowell, R. Celestre, H. A. Padmore, and Z. Hussain, J. Cryst. Growth 210, 395 (2000). 
N. T. Barrett, P. N. Gibson, G. N. Greaves, P. Mackle, K.J. Roberts, and M.

Sacchi, Journal of Physics D: Applied Physics 22, 542 (1989).

S. A. McHugo, A. C. Thompson, G. Lamble, C. Flink, and E. R. Weber, Physica B 273-274, 371 (1999).

L. Magaud, S. Guillet, and T. Lopez-Rios, Physica B 225, 225 (1996).

A. Cros, M. O. Aboelfotoh, and K. N. Tu, J. Appl. Phys. 67, 3328 (1990).

Z. An, C. Kamezawa, M. Hirai, M. Kusaka, and M. Iwami, J. Physical Soc. Japan

71, 2948 (2002).

A. Cros, M. O. Aboelfotoh, and K. N. Tu, J. Appl. Phys. 67, 3328 (1990).

S. K. Estreicher and D. West, in 12th Workshop on Crystalline Silicon Solar Cell

Materials and Processes, edited by B. L. Sopori (NREL, Golden, CO, 2002), p. 147.

S. P. Murarka and C. C. Chang, Appl. Phys. Letters 37, 639 (1980).

T. Buonassisi, M. Heuer, A. A. Istratov, E. R. Weber, Z. Cai, B. Lai, M. Marcus,

J. Lu, G. A. Rozgonyi, R. Schindler, R. Jonczyk, and J. A. Rand, in 13th

Workshop on Crystalline Silicon Solar Cell Materials and Processes, edited by B. Sopori (NREL, Golden, CO, 2003), p. 96.

64 F. M. d'Heurle, A. Cros, R. D. Frampton, and E. A. Irene, Phil. Mag. B 55, 291 (1987).

V. V. Voronkov and R. Falster, J. Appl. Phys. 86, 5975 (1999).

S. Sadamitsu, A. Sasaki, M. Hourai, S. Sumita, and N. Fujino, Jap. J. Appl. Phys. 30, 1591 (1991).

M. A. Marcus and J. E. Bower, J. Appl. Phys. 82, 3821 (1997). 
M. Apel, I. Hanke, R. Schindler, and W. Schröter, J. Appl. Phys. 76, 4432 (1994). H. Hieslmair, S. A. McHugo, A. A. Istratov, and E.R.Weber, in Properties of Crystalline Silicon, edited by R. Hull (INSPEC, Short Run Press, Exeter, 1999), p. 775. M. Kittler and W. Seifert, Solid State Phenomena 95-96, 197 (2004). CRC Handbook of Chemistry and Physics, 84th Edition (CRC Press, USA, 2003). 
Table I. The enthalpies of formation per mol per oxygen atom at $298.15 \mathrm{~K}$ for various oxidized metal species. It is shown that the binding energy of oxygen to silicon is far greater than that of oxygen to iron or to copper. The same is not true for all metals, e.g. hafnium. Data are from Ref. 71.

\begin{tabular}{lc}
\hline Compound & $\begin{array}{c}\text { ? } \mathrm{H}^{\circ} \\
(\mathrm{kJ} / \mathrm{mol})\end{array}$ \\
\hline $1 / 2 \mathrm{HfO}_{2}$ & -572.4 \\
$1 / 2 \mathrm{ZrO}_{2}$ & -550.3 \\
$1 / 2 \mathrm{TiO}_{2}$ & -472.0 \\
$\mathbf{1} / 2 \mathrm{SiO}_{2}$ & $-\mathbf{4 5 5 . 4}$ \\
$1 / 4 \mathrm{Fe}_{2} \mathrm{SiO}_{4}$ & -370.0 \\
$1 / 4 \mathrm{Fe}_{3} \mathrm{O}_{4}$ & -279.6 \\
$1 / 3 \mathrm{Fe}_{2} \mathrm{O}_{3}$ & -274.7 \\
$\mathrm{Cu}_{2} \mathrm{O}$ & -168.6 \\
$\mathrm{CuO}$ & -157.3 \\
\hline
\end{tabular}




\section{FIGURES}

Note for the referees / editorial staff: in order to reduce the file size, the figures were pasted into this Word document as medium-resolution graphical images. This resulted in a certain loss of quality of tick and axes labels. High quality postscript files will be submitted for production.

Buonassis et al - Figure 1 (of 9)
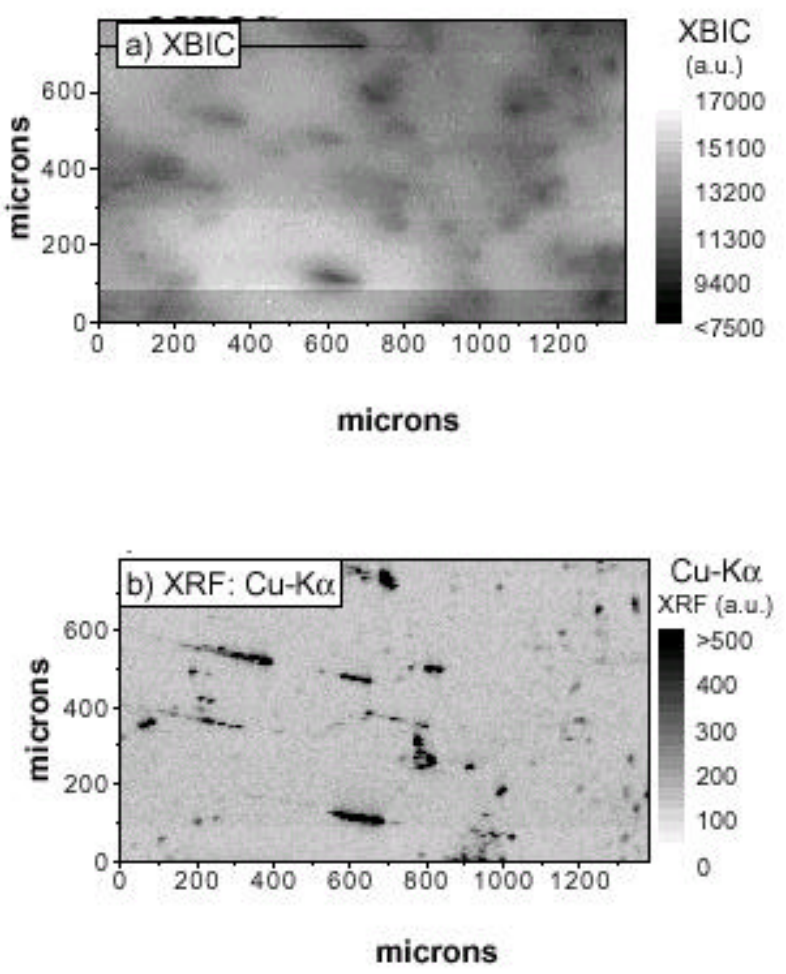
Buonassisi et al - Fig. 2 (of 9)

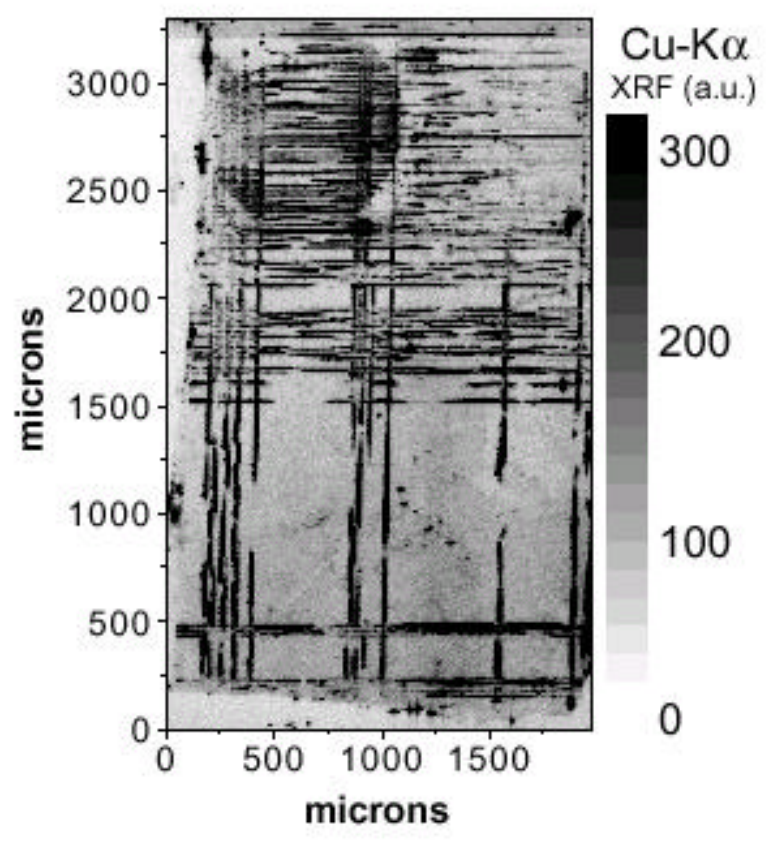


Buonassisi et al. Fig. 3 (of 9)

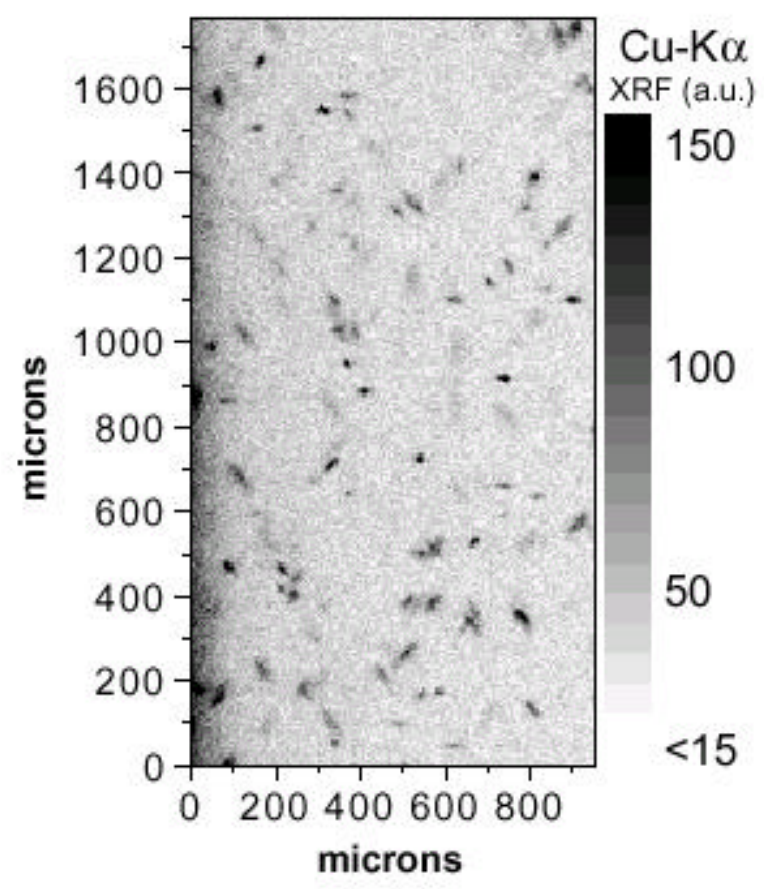


Buonassisi et al. Fig. 4 (of 9)

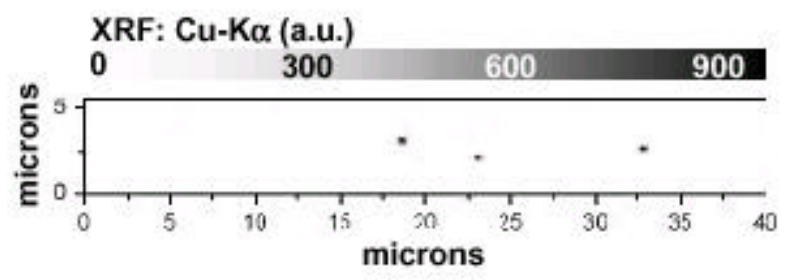


Buonassisi et al. - Fig. 5 (of 9)
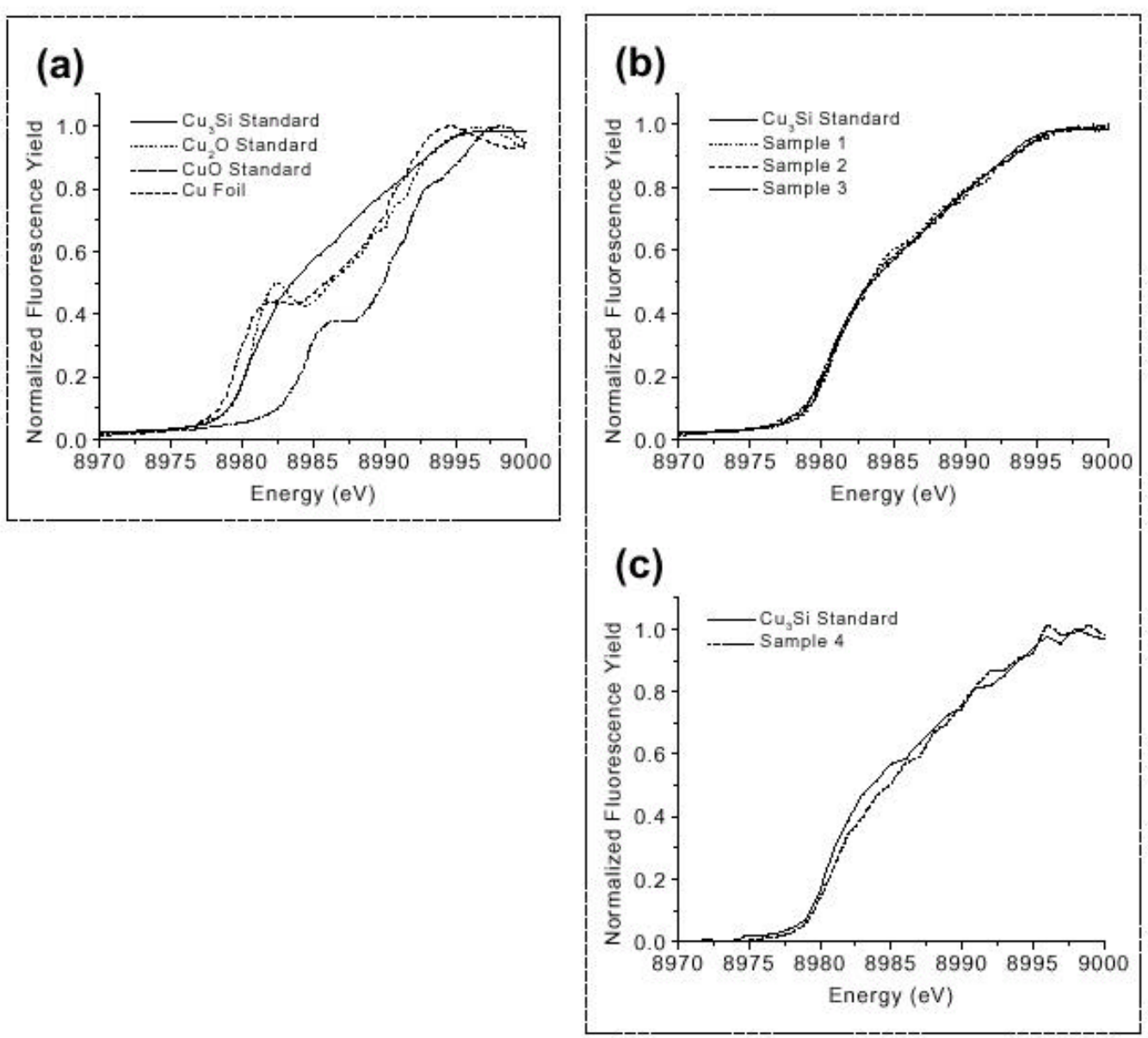
Buonassisi et al. - Fig. 6 (of 9)

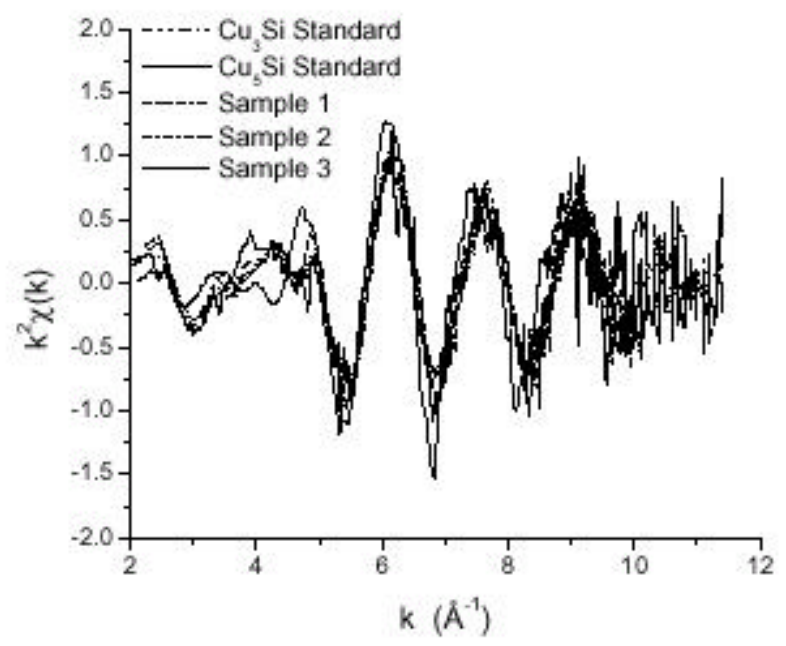


Buonassisi et al. - Fig. 7 (of 9)
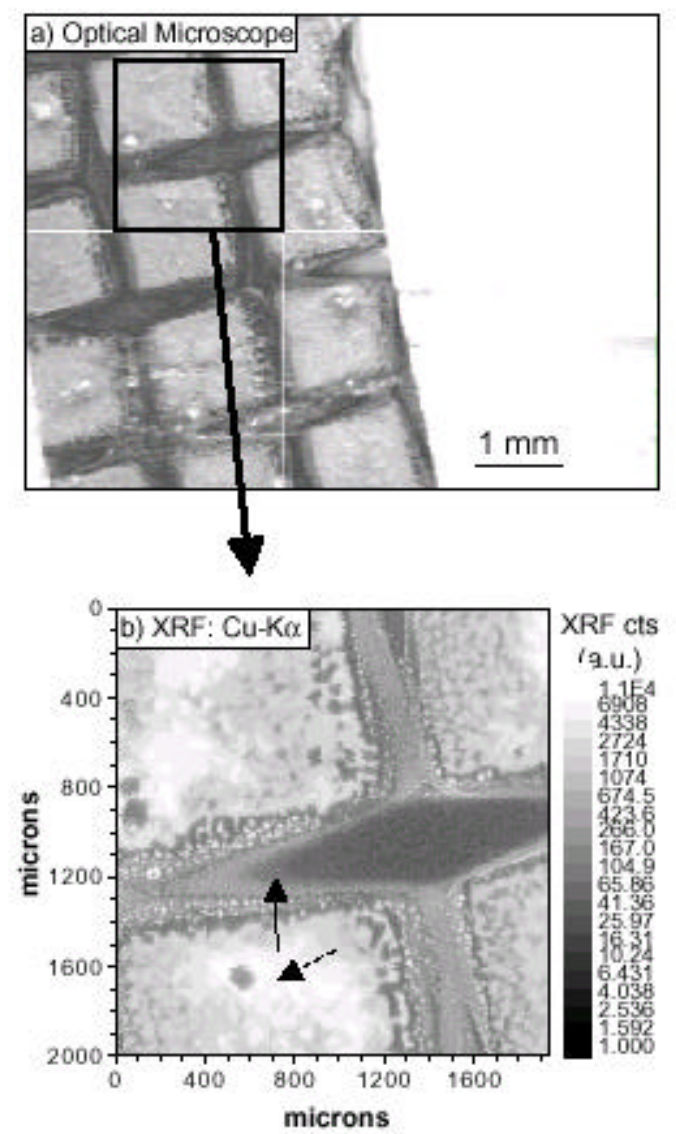
Buonassisi et al - Fig. 8 (of 9)

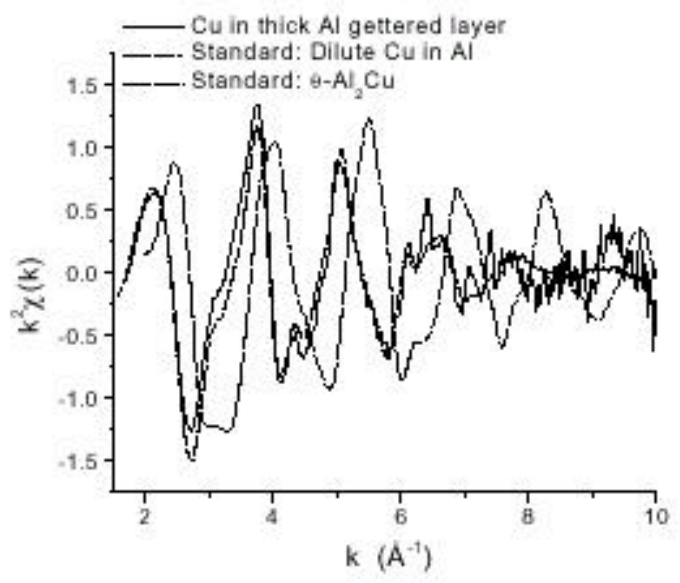


Buonassisi et al - Fig 9 (of 9)

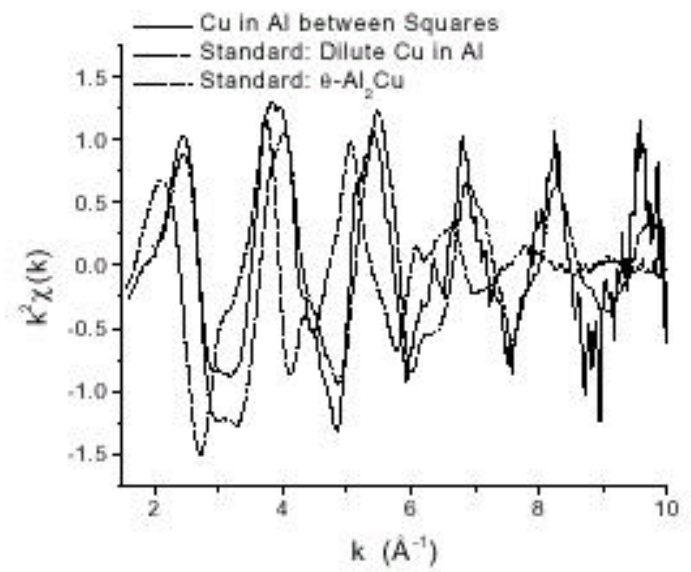

